\title{
ANALISIS FAKTOR-FAKTOR YANG MEMPENGARUHI PENYERAPAN TENAGA KERJA PADA SEKTOR PERHOTELAN DI PROVINSI MALUKU DENGAN MENGGUNAKAN METODE REGRESI DATA PANEL
}

\author{
M. Yahya Matdoan1) \\ M. W. Talakua2) \\ 1,2)Program Studi Statistika, FMIPA, Universitas Pattimura \\ e-mail: keepyahya@gmail.com
}

\begin{abstract}
ABSRACT
The hotel sector is one of the sectors that has made a major contribution to employment and economic development in Maluku Province. The more the population, the more difficult it is to find work. The purpose of this study is to analyze the effect of the variable number of accommodation, number of occupancy, number of available beds and minimum wage of employees on labor absorption in the hotel sector in Maluku Province. One method that can be used to solve this problem is the Panel Data Regression method. Panel data regression is a combination of time series data and cross section data. This method can be used to determine the relationship between two or more variables that are quantitative in nature, so that one variable can be predicted from the other variables. The Panel Data Regression model used in this study is the Fixed Effect Model (FEM) with the results obtained, namely that there are three variables that affect labor absorption in the hotel sector in Maluku Province, namely the number of accommodation, the number of occupancy and the minimum wage of employees. Meanwhile, the number of available beds has no effect on labor absorption in the hotel sector in Maluku Province.
\end{abstract}

Keywords: hospitality, labor, panel data regression

\begin{abstract}
ABSTRAK
Sektor perhotelan merupakan salah satu sektor yang memberikan kontribusi besar dalam penyerapan tenaga kerja dan pembangunan ekonomi di Provinsi Maluku. Jika semakin bertambahnya jumlah penduduk maka semakin sulitnya mencari pekerjaan. Tujuan penelitian ini yaitu untuk menganalisis pengaruh variabel jumlah akomodasi, jumlah hunian, jumlah tempat tidur yang tersedia dan upah minimum karyawan terhadap penyerapan tenaga kerja pada sektor perhotelan di Provinsi Maluku. Salah satu metode yang dapat digunakan untuk memecahkan masalah tersebut yaitu metode Regresi Data Panel. Regresi data panel merupakan gabungan antara data time series dan data cross section. Metode ini dapat digunakan untuk mengetahui hubungan antara dua atau lebih variabel yang bersifat kuantitatif, sehingga salah satu variabel dapat diprediksi dari variabel lainnya. Penelitian ini diperoleh hasil bahwa terdapat tiga variabel yang berpengaruh terhadap penyerapan tenaga kerja pada sektor perhotelan di Provinsi Maluku yaitu jumlah akomodasi, jumlah hunian dan upah minimum karyawan. Sementara jumlah tempat tidur yang tersedia tidak berpengaruh terhadap penyerapan tenaga kerja pada sektor perhotelan di Provinsi Maluku.
\end{abstract}

Kata kunci: perhotelan, tenaga kerja, regresi data panel 
Pembangunan ekonomi merupakan cita-cita setiap bangsa di dunia tanpa terkecuali Indonesia. Pembagunan ekonomi erat kaitanya dengan perkembangan pendapatan nasional, percepatan pertumbuhan ekonomi, ketimpangan kesejahteraan dan masalah penyerapan tenaga kerja. Penyerapan tenaga kerja merupakan salah satu faktor pendukung dalam pembangunan ekonomi dengan tujuan untuk mencapai tingkat pembangunan ekonomi yang merata di suatu daerah (Simanjuntak, 2001)

Tenaga kerja adalah penduduk yang sudah atau sedang berkerja dan yang sedang mencari pekerjaan, serta melakukan kegiatan lain seperti bersekolah atau mengurus rumah tangga, dengan batasan umur 15 tahun. Selain itu, kesempatan kerja merupakan besarnya permintaan perusahaan akan tenaga kerja pada dasarnya permintaan masyarakat terhadap barang dan jasa yang dihasilkan perusahaan tersebut (Simanjuntak dan Rahmadi, 2016). Sektor perhotelan merupakan sektor yang siap dalam penyerapan tenaga kerja karena tidak hanya menciptakan lapangan pekerjaan baru tetapi juga dapat menghidupkan orang yang tinggal di sekitar hotel tersebut. Sektor ini merupakan salah satu sektor yang memberikan kontribusi besar dalam penyerapan tenaga kerja dan peningkatan pembangunan ekonomi di Provinsi Maluku. Hotel yang terdapat di Provinsi Maluku terdiri dua jenis yaitu hotel bintang dan non bintang dengan berbagai kelas dan beragam fasilitas.

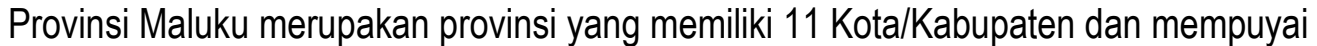
potensi yang besar dari sektor perhotelan. Sebagai salah satu provinsi yang memiliki keindahan wisata, Provinsi Maluku juga merupakan daerah yang kaya akan peninggalan sejarah dan memiliki beragam budaya dan bahasa yang tersebar di setiap kabupaten/kota. Hal ini yang membuat daya tarik wisatawan untuk datang dan berkunjung di Provinsi Maluku sehingga banyak pengusaha yang tertarik untuk mengembangkan usahannya di sektor perhotelan. Jika semakin bertambahnya jumlah penduduk maka semakin sedikit lapangan pekerjaan yang tersedia dan dengan semakin berkembangnya teknologi maka pihak perusahan atau pengusaha banyak menggunakan mesin dalam proses pekerjaan (Alghofari dan Pujiyono, 2011). Selain itu, pihak perusahan merekrut tenaga kerja yang layak memiliki kriteria sumberdaya tertentu dalam menerima tenaga kerja seperti memiliki kemampuan dan lebih terampil dalam bekerja, sehingga sumberdaya yang tidak memiliki kemampuan dan keterampilan khusus akan tersingkirkan dari persaingan tenaga kerja dan tidak mendapatkan pekerjaan yang layak, bahkan menjadi pengangguran sehingga mengakibatkan terjadinya kemiskinan dan ketimpangan kesejahteraan di setiap daerah (Sukmawati, 2018).

Masalah ketenagakerjaan merupakan salah satu masalah yang sering muncul dan selalu dihadapai pada saat pengambilan kebijakan ekonomi baik pemerintah daerah maupun pusat, dan tak terkecuali Provinsi Maluku. Hal ini diakibatkan karena terjadinya peningkatan jumlah penduduk yang tidak diimbangi oleh bertambahnya penyedia lapangan pekerjaan sehingga menimbulkan pengangguran (Setiawan \& Yuliati, L, 2019). Jika permasalahan ini merupakan masalah yang belum dapat terselesaikan sampai pada saat ini, maka dari itu peran dari pemerintah sangat dibutukan untuk mengurangi atau bahkan menyelesaikan permasalahan ketenagakerjaan (Wijayanti, 2018).

Analisis regresi merupakan metode statistika yang digunakan untuk mengetahui hubungan antara dua atau lebih variabel yang bersifat kuantitatif, sehingga salah satu variabel dapat diprediksi dari variabel lainnya (Matdoan, 2020). Regresi data panel merupakan salah satu pengembangan dari metode analisis regresi. Analisis Regresi data panel merupakan gabungan antara data time series dan data cross section (Melliana, 2013). Terdapat beberapa kelebihan dalam regresi data panel, yaitu mampu mengontrol keheterogenan individual, dengan data cross-section diasumsikan homogen tanpa ada pengaruh lain yang masuk, seperti waktu, sedangkan pada data time series, data yang diperoleh akan berubah setiap periode waktu. Regresi data panel memiliki tiga 
pendekatan, yaitu Common Effect Model (CEM), Fixed Effect Model (FEM), dan Random Effect Model (REM) (Candradewi, 2016).

Metode CEM merupakan metode yang menggambungkan seluruh data baik data cross section maupun data time series. Metode CEM mengasumsikan bahwa intercept dan slope pada unit cross section dan time series. Secara umum model persamaan metode CEM sebagai berikut (Sriyana, 2015).

$$
Y_{i t}=\beta_{0}+\beta_{1} X_{1 i t}+\beta_{2} X_{2 i t}+\cdots+\beta_{j} X_{j i t}+\varepsilon_{i t}
$$

Metode FEM merupakan metode yang mengasumsikan koefisien slope bernilai konstan tapi intercept bersifat tidak konstan. Secara umum model persamaan FEM sebagai berikut (Pangestika, 2015)

$$
Y_{i t}=\beta_{0 i t}+\beta_{1} X_{1 i t}+\beta_{2} X_{2 i t}+\cdots+\beta_{j} X_{j i t}+\varepsilon_{i t}
$$

Selanjutnya metode REM merupakan metode yang mengasumsikan perbedaan karateristik unit dan periode waktu diakomodasikan pada error atau residual dari model yakni unit dan periode waktu. Oleh karena itu, random error dalam REM perlu diurai menjadi error gabungan dan error untuk periode waktu. Secara umum model persamaan REM sebagai berikut (Nachrowi \& Usman, 2006).

$$
Y_{i t}=\beta_{0 i t}+\beta_{1} X_{1 i t}+\beta_{2} X_{2 i t}+\cdots+\beta_{j} X_{j i t}+\left(\mu_{i}+\varepsilon_{i t}\right)
$$

Berdasarkan latar belakang yang telah diuraikan, sehingga penulis bertujuan untuk melakukan penelitian degan judul yaitu untuk menganalisis faktor-faktor yang mempengaruhi penyerapan tenaga kerja pada sektor perhotelan di Provinsi Maluku dengan menggunakan regresi data panel.

\section{METODE}

\section{Sumber Data}

Data yang diperoleh dalam penelitian ini berupa data sekunder yang diperoleh dari Badan Pusat Statistik (BPS) Provinsi Maluku. Data yang diperoleh merupakan data yang berasal dari hasil publikasi BPS, Maluku Dalam Angka dari tahun 2016-2020.

\section{Variabel Penelitian}

Variabel yang digunakan dalam penelitian ini terdiri dari dua variabel yaitu variabel dependen dan variabel independen. Variabel dependen $(y)$ yaitu penyerapan tenaga kerja pada sektor perhotelan, sementara variabel independen terdiri dari 4 variabel yaitu Variabel Jumlah Akomodasi $\left(X_{1}\right)$, Variabel Jumlah Hunian $\left(X_{2}\right)$, Variabel Jumlah Tempat Tidur yang Tersedia $\left(X_{3}\right)$ dan Variabel Upah Minimum Karyawan $\left(X_{4}\right)$.

\section{Tahapan Penelitian}

Tahapan yang dilakukan dalam penelitian ini yaitu sebagai berikut.

1. Menentukan data panel yang akan dianalisis.

2. Melakukan uji spesifikasi model untuk memperoleh model yang paling sesuai.

3. Melakukan uji asumsi residual, yakni uji heteroskedastisitas dan autokorelasi.

4. Membentuk model regresi data panel terbaik berdasarkan uji spesifikasi model. 
5. Melakukan uji parameter regresi yang meliputi: uji koefisien regresi secara simultan, uji parameter individual, dan uji koefisien determinasi.

Adapun prosedur dalam penelitian ini dapat dilihat pada Gambar 1.

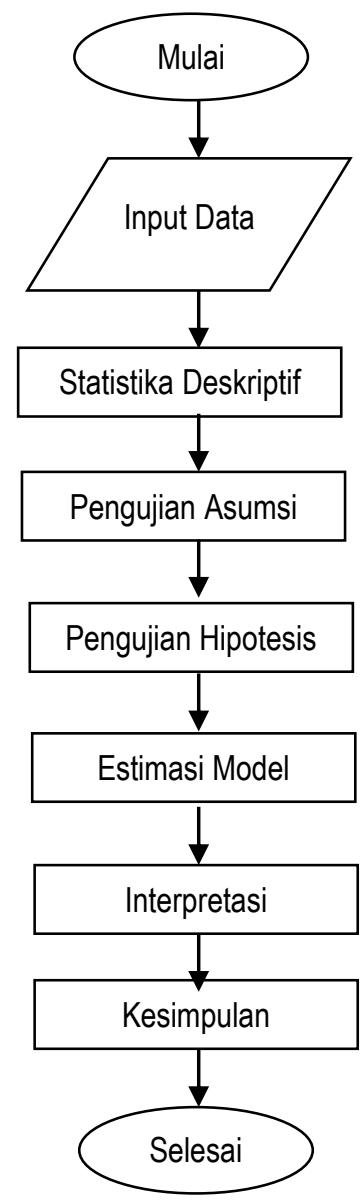

Gambar 1. Flowchart alur penelitian

\section{HASIL DAN PEMBAHASAN}

\section{a. Analisis Deskriptif Variabel Penyerapan Tenaga Kerja}

Penyerapan tenaga kerja merupakan jumlah tertentu dari tenaga kerja yang digunakan dalam suatu unit usaha tertentu atau dengan kata lain penyerapan tenaga kerja pada sektor perhotelan merupakan banyaknya tenaga kerja yang bekerja dalam usaha jasa perhotelan. Analisis statistik deskriptif dapat digunakan untuk mengetahui ukuran minimum dan maksimum, serta ratarata dari suatu data penelitian. Hasil analisis statistik deskriptif jumlah penyerapan tenaga kerja pada sektor perhotelan dapat dilihat pada Gambar 2. 


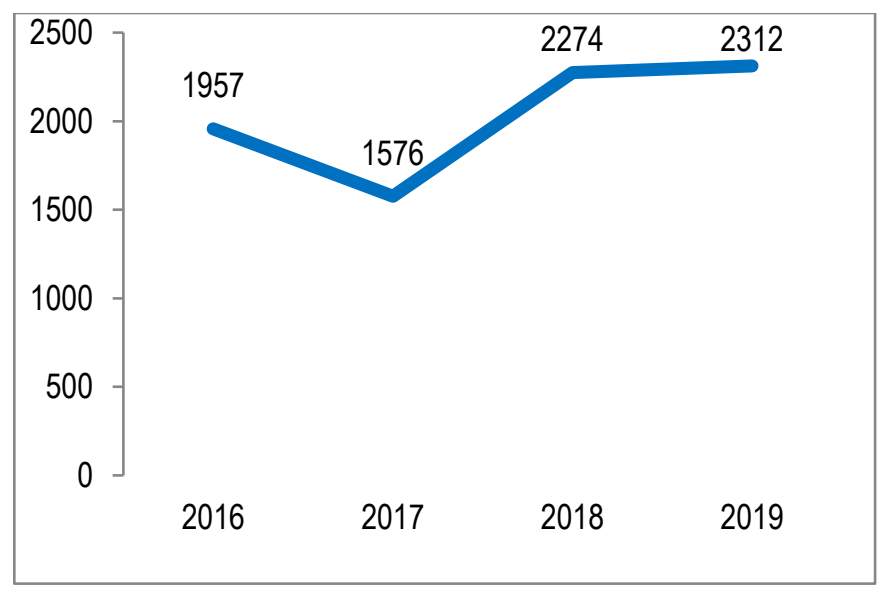

Gambar 2. Jumlah tenaga kerja pada sektor perhotelan di Provini Maluku

Berdasarkan Gambar 2, dapat jumlah tenaga kerja pada sekor pehotelan dari tahun 20162019 selalu mengalami fluktuasi. Pada tahun 2016 jumlah tenaga kerja pada sektor perhotelan sebanyak 1957 pekerja, kemudian pada tahun 2017 mengalami penurunan yaitu sebanyak 1.576 dan pada tahun 2018 mengalami peningkatan yaitu sebanyak 2.274 dan pada tahun 2019 jumlah tenaga kerja pada sektor perhotelan terus mengalami peningkatan yaitu sebesar 2.312 pekerja. Selanjutnya sebaran tenaga kerja pada sektor perhotelan di Kabupaten/Kota di Provinsi Maluku dapat dilihat pada Gambar 3 berikut.

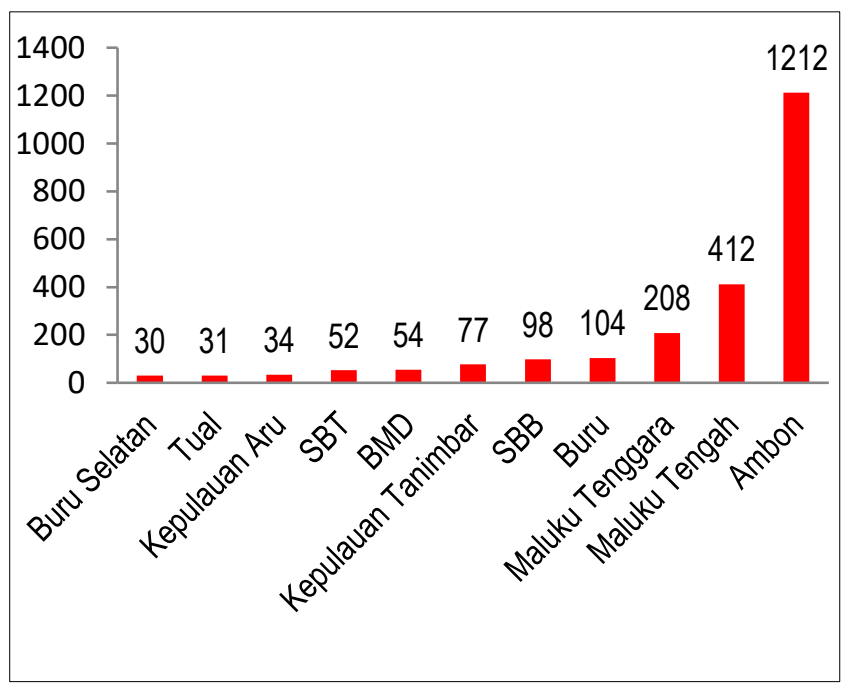

Gambar 3. Jumlah tenaga kerja sektor perhotelan pada Kabupaten/Kota di Provinsi Maluku Tahun 2020

Berdasarkan Gambar 3, dapat dilihat bahwa jumlah tenaga kerja pada sekor perhotelan di Kabupaten/Kota di Provinsi Maluku yaitu sebanyak 2.312. Kabupaten/kota yang memiliki tenaga kerja terbanyak yaitu Kota Ambon sebanyak 1.212 kemudian Maluku Tengah sebanyak 412 pekerja, Kabupaten Maluku Tenggara sebanyak 208 pekerja dan Kabupaten Buru sebanyak 104 pekerja. 
Selanjutnya Kabupaten yang memiliki tenaga kerja pada sektor perhotelan terendah yaitu Kabupaten Buru Selatan dengan jumlah sebanyak 30 pekerja dan Kota Tual sebanyak 31 pekerja.

\section{b. Pengujian Asumsi}

Pengujian asumsi dengan maksud memberikan gambaran tentang sejauh mana persyaratan telah dipenuhi sesuai dengan teknik analisis statistik yang direncanakan. Berikut merupakan beberapa pengujian yang harus dipenuhi dalam menggunakan metode analisis regresi. Pengujian asumsi dalam penelitian ini terdiri dari uji normalitas, uji multikolinieritas dan uji heterokedastisitas.

\section{Hasil Uji Normalitas}

Untuk menguji normalitas dari suatu data dapat digunakan metode Jarque Bera test. Metode Jarque Bera test atau ( $\mathrm{J}-B$ test), membandingkan $J B$ hitung dengan tabel. Jika $J B_{\text {hitung }}<$ nilai $J B_{\text {tabel }}$ maka data berdistribusi normal atau nilai probability > derajat kepercayaan yang ditentukan (Ningsih, 2011). Uji normalitas dalam penelitian ini variabel dependen dapat dilihat pada Gambar 4.

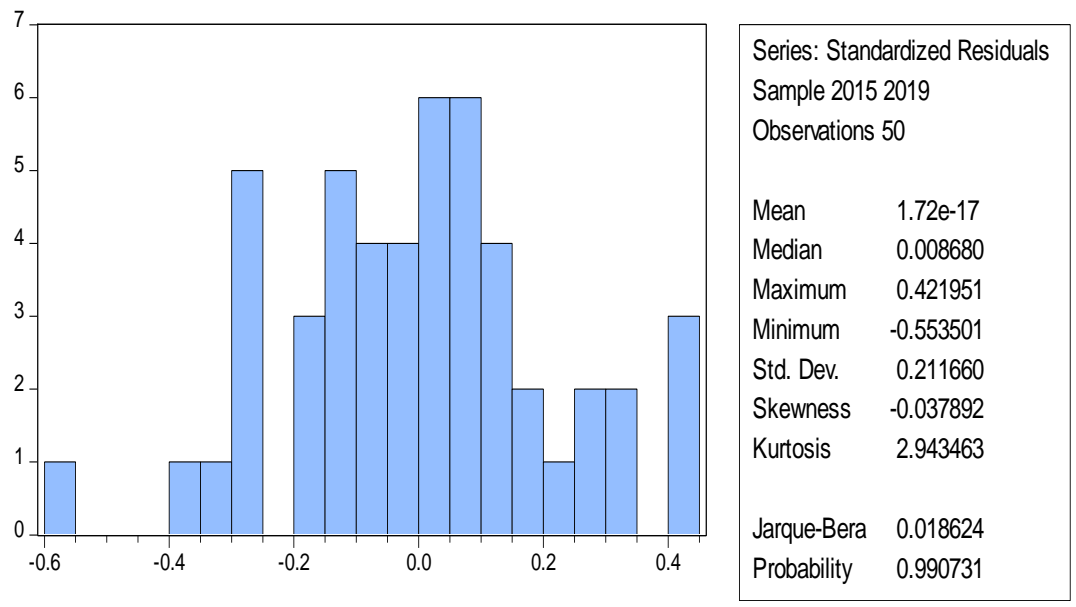

Gambar 4. Hasil uji normalitas menggunakan Jarque-Bera Test

Berdasarkan hasil uji normalitas pada Gambar 4, dapat dilihat bahwa nilai probability sebesar 0,990731 dimana 0,990731 > 0,05 dengan demikian, maka dapat disimpulkan bahwa data terdistribusi normal sehingga asumsi normalitas terpenuhi.

\section{Hasil Uji Multikolinearitas}

Multikolinearitas merupakan situasi dimana adanya korelasi antara variabel bebas dengan variabel bebas lainnya. Menurut Gujarati (2003) mengatakan bahwa bila korelasi antara dua variabel bebas melebihi 0,8 maka multikolinearitas menjadi masalah yang serius. Gujarati juga menambahkan bahwa, apabila korelasi antara variabel penjelas tidak lebih besar dibanding korelasi variabel terikat dengan masing-masing variabel penjelas, maka dapat dikatakan tidak terdapat masalah yang serius. Oleh karena itu, dapat disimpulkan bahwa apabila angka korelasi lebih kecil dari 0,8 maka dapat dikatakan variabel independen tidak mengandung masalah multikolinearitas. Adapun hasil uji multikolinearitas dapat diamati pada tampilan Tabel 1. 
Tabel 1. Uji Multikolinearitas dengan Matriks Korelasi

\begin{tabular}{|c|c|c|c|c|}
\hline & $\mathbf{X}_{1}$ & $\mathbf{X}_{2}$ & $\mathbf{X}_{3}$ & $\mathbf{X}_{4}$ \\
\hline $\mathbf{X}_{1}$ & 1 & 0,615 & 0,720 & 0,112 \\
\hline $\mathbf{X}_{2}$ & 0,615 & 1 & 0,698 & 0,027 \\
\hline $\mathbf{X}_{3}$ & 0,720 & 0,698 & 1 & 0,015 \\
\hline $\mathbf{X}_{4}$ & 0,112 & 0,027 & 0,015 & 1 \\
\hline
\end{tabular}

Berdasarkan Tabel 1, diketahui bahwa model regresi yang digunakan tidak mengandung masalah multikolinearitas atau dengan kata lain sudah terbebas dari masalah multikolinearitas karena hubungan/korelasi semua variabel independen menghasilkan nilai matriks korelasi $<0,8$.

\section{Uji Heterokedastisitas}

Uji heteroskedastisitas dilakukan unutuk menguji apakah dalam model regresi terjadi ketidaksamaan varians dari residual (Syukriyah, A, 2011). Uji heteroskedastisitas pada peneltian ini dilakukan dengan menggunakan uji glatser.

\section{Hipotesis}

Hipotesis uji heterokedastisitas yaitu sebagai berikut:

$\mathrm{H}_{0}$ : Terdapat masalah heterokodastitas dalam model regresi

$\mathrm{H}_{1}$ : Tidak terdapat masalah heterokodastitas dalam model regresi

\section{Aturan Keputusan}

Jika nilai signifikansi lebih dari besar 0,05 (alpha) maka $\mathrm{H}_{0}$ diterima sebaliknya jika nilai signifikansi lebih kecil 0,5 (alpha) maka Ho ditolak (Kencana, E. N, 2019). Hasil uji heteroskedastisitas dengan menggunakan uji Glejser dapat dilihat pada Tabel 2 berikut.

Tabel 2. Hasil Uji Heteroskedastisitas

\begin{tabular}{ccccc}
\hline \hline Variable & Coefficient & Std. Error & t-Statistic & Prob. \\
\hline \hline C & 78,48420 & 47,94036 & 1,637122 & 0,1079 \\
X1 & $-0,454383$ & 0,606176 & $-0,749589$ & 0,4570 \\
X2 & 0,397057 & 0,168334 & $-0,058746$ & 0,2232 \\
X3 & $-0,275991$ & 0,136892 & $-0,016118$ & 0,4920 \\
X4 & $-1,96 \mathrm{E}-05$ & $2,25 \mathrm{E}-05$ & $-0,869285$ & 0,3888 \\
\hline \hline
\end{tabular}

Berdasarkan Tabel 2, dapat dilihat bahwa nilai $p$-value yang ditunjukan dengan nilai Prob. Untuk semua variabel penelitian lebih sebesar dari 0,05. Oleh karena itu, dapat disimpulkan bahwa tidak terdapat kasus heteroskedastisitas.

\section{c. Uji Hipotesis Penelitian}

Uji hipotesis dalam penelitian ini bertujuan untuk menguji apakah terdapat pengaruh positif Akomodasi $\left(X_{1}\right)$, Jumlah Hunian $\left(X_{2}\right)$ Jumlah Tempat Tidur yang Tersedia $\left(X_{3}\right)$ dan Jumlah Upah Minimum Karyawan $\left(X_{4}\right)$ secara bersama-sama terhadap Penyerapan Tenaga Kerja pada Sektor 
Perhotelan (Y) di Provinsi Maluku. Untuk menguji hipotesis tersebut, dilakukan dengan menggunakan regresi data panel.

Pemodelan dalam menggunakan teknik analisis regresi data panel dapat menggunakan tiga pendekatan alternatif metode dalam pengolahannya. Pendekatan-pendekatan tersebut yaitu Commond Effect Model (CEM), Fixed Effect Model (FEM) dan Random Effect Model (REM) (Jaya, I. G. N. M., \& Sunengsih, N, 2009). Dari ketiga pendekatan tersebut akan dipilih model terbaik.

\section{a. Uji Chow/Uji Likelihood}

Uji Chow/uji Likelihood merupakan pengujian untuk melihat model mana yang tepat antara Commond Effect Model (CEM) dan Fixed Effect Model (FEM). Hipotesis yang digunakan dalam penelitian ini adalah:

$H_{0}: \beta_{1}=\beta_{2}=\cdots=\beta_{k}=0$ (Commond effect Model).

$H_{1}$ : Minimal ada satu $\beta_{i} \neq 0$ (Fixed effect Model).

Hasil dari uji Chow dapat dilihat dengan memperhatikan nilai probability cross section $F$. Selanjutnya, diperoleh nilai probability cross section $F$ yang dijelaskan oleh Tabel 3.

Tabel 3. Uji Chow/Ni Likelihood

\begin{tabular}{lccr}
\hline \multicolumn{1}{c}{ Tes Efek } & Statistik & d.f & P-Value \\
\hline Cross-Section F & 11,307244 & $(10,40)$ & 0,0259 \\
Cross-Section Chi Square & 15,552812 & 10 & 0,0132 \\
\hline
\end{tabular}

Berdasarkan Tabel 3, diperoleh nilai $P$-value Cross-section $F$ sebesar 0,0259 kurang dari $\alpha=0,05$. Dan nilai $P$-value Cross-section Chi Square sebesar 0,0132 juga kurang dari $\alpha=0,05$ sehingga keputusan yang diambil adalah menolak $H_{0}$ atau model yang tepat adalah Fixed Effect Model (FEM). Selain itu, nilai statistik cross-section $F=11,307244$ yang merupakan nilai $F_{\text {hitung }}$ dan diketahui df $(4,50)$ pada taraf kepercayaan $95 \%(\alpha=0,05)$ maka diperoleh $F_{\text {tabel }}$ adalah 2,557. Karena nilai dari $F_{\text {hitung }}$ sebesar 11,307244 lebih dari $F_{\text {tabel }}$ sebesar 2,557 maka tolak $H_{0}$ atau model yang tepat adalah model FEM.

\section{b. Uji Hausman}

Uji Hausman Merupakan pengujian untuk menentukan metode mana yang paling tepat digunakan antara random effect model (REM) atau fixed effect Model (FEM). Hipotesis yang digunakan dalam penelitian ini adalah:

$H_{0}$ : Korelasi $\left(X_{i t}, \varepsilon_{i t}\right)=0$ (Random effect Model $)$

$H_{1}$ : Korelasi $\left(X_{i t}, \varepsilon_{i t}\right) \neq 0$ (Fixed effect Model)

Selanjutnya hasil uji Hausman dapat dilihat pada Tabel 4.

Tabel 4. Uji Hausman

\begin{tabular}{cccc}
\hline Test Summary & Statistik chi-squared & d.f & $P$-Value \\
\hline Cross-Section random & 11,618049 & 4 & 0,0295 \\
\hline
\end{tabular}


Berdasarkan Tabel 4, diperoleh Nilai Uji chi squared sebesar 11,618049 dan diketahui df(4) pada taraf kepercayaan $95 \%(\alpha=0,05)$ maka diperoleh nilai $\chi^{2}$ tabel adalah 9,487 . Terlihat uji statistik Hausman sebesar 11,618049 lebih dari $\chi^{2}$ tabel adalah 9,487 sehingga tolak $\mathrm{H}_{0}$. Hal ini juga ditunjukan melalui nilai $p$-value cross section random sebesar 0,0295 kurang dari $\alpha=0,05$. Oleh karena itu, dapat disimpulkan bahwa tolak $\mathrm{H}_{0}$ atau model yang tepat adalah fixed effect model (FEM).

\section{c. Estimasi Model}

Estimasi model yang yang akan dibahas yaitu model penyerapan tenaga kerja di Provinsi Maluku dengan pendekatan Fixed Effect Model (FEM). Model ini diestimasi berdasarkan variabel dependen yaitu, Penyerapan tenaga kerja $(Y)$ dengan variabel independen yaitu, jumlah akomodasi $\left(X_{1}\right)$, jumlah hunian $\left(X_{2}\right)$, jumlah tempat tidur yang tersedia $\left(X_{3}\right)$ dan upah minimum karyawan $\left(X_{4}\right)$. Diperoleh model penyerapan tenaga kerja di Provinsi Maluku sebagai berikut.

$$
\hat{Y}_{i t}=\hat{\alpha}_{i}-0,872430 X_{1 i t}+0,190559 X_{2 i t}+0,125480 X_{3 i t}+0,000037 X_{4 i t}
$$

\section{d. Pengujian Parameter Regresi \\ 1. Uji Simultan (Uji F)}

Uji F dilakukan untuk menguji apakah variabel independen secara keseluruhan memiliki pengaruh terhadap variabel dependen. Hipotesis uji simultan adalah sebagai berikut:

$H_{0}: \beta_{1}=\beta_{2}=\cdots=\beta_{k}=0$; Ada pengaruh variabel independen secara keseluruhan terhadap variabel dependen.

$H_{1}: \beta_{1}=\beta_{2}=\cdots=\beta_{j} \neq 0$; Tidak ada pengaruh antara variabel independen secara keseluruhan terhadap variabel dependen.

Berdasarkan hasil estimasi model fixed effect, diperoleh Tabel 5.

Tabel 5. Uji simultan (Uji F)

\begin{tabular}{ll}
\hline adjusted $R$ squared & 0,927435 \\
Sum Squared Resid & 372364,1 \\
$F$-hitung & 159,7600 \\
$P$-value(F-hitung) & 0,000000 \\
\hline
\end{tabular}

Berdasarkan Tabel 5, diperoleh nilai $F_{\text {hitung }}$ sebesar 159,7600 dengan nilai $P$-value ( $F_{\text {hitung }}$ ) sebesar 0,000000. Dengan taraf kepercayaan $95 \%(\alpha=0,05)$ diperoleh nilai $F_{\text {tabel }}$ sebesar 2,557 . Karena nilai $F_{\text {hitung }}$ sebesar 159,7600 lebih dari $F_{\text {tabel }}$ 2,557. maka berdasarkan kaidah pengambilan keputusan, sehingga tolak $H_{0}$ yang berarti bahwa ada pengaruh antara variabel independen secara keseluruhan terhadap variabel dependen.

\section{Uji parsial (Uji t)}

Uji $t$ bertujuan untuk untuk melihat signifikansi dari pengaruh variabel independen $(X)$ secara parsial (sendiri-sendiri) terhadap variabel dependen (Y) (Kurniawan, D, 2008).

Hipotesis sebagai berikut: 
$H_{01}$ : Variabel akomodasi $\left(\mathrm{X}_{1}\right)$ tidak berpengaruh signifikan terhadap penyerapan tenaga kerja pada sektor perhotelan $(Y)$.

$H_{11}$ : Variabel akomodasi $\left(\mathrm{X}_{1}\right)$ berpengaruh signifikan terhadap penyerapan tenaga kerja pada sektor perhotelan $(Y)$.

$H_{02}$ : Variabel jumlah hunian $\left(\mathrm{X}_{2}\right)$ tidak berpengaruh signifikan terhadap penyerapan tenaga kerja pada sektor perhotelan $(\mathrm{Y})$.

$H_{12}$ : Variabel jumlah hunian $\left(\mathrm{X}_{2}\right)$ berpengaruh signifikan terhadap penyerapan tenaga kerja pada sektor perhotelan $(Y)$.

$H_{03}$ : Variabel jumlah tempat tidur yang tersedia $\left(X_{3}\right)$ tidak berpengaruh signifikan terhadap penyerapan tenaga kerja pada sektor perhotelan (Y).

$H_{13}$ : Variabel jumlah tempat tidur yang tersedia $\left(\mathrm{X}_{3}\right)$ berpengaruh signifikan terhadap penyerapan tenaga kerja pada sektor perhotelan $(\mathrm{Y})$.

$H_{04}$ Variabel upah minimum karyawan $\left(\mathrm{X}_{4}\right)$ tidak berpengaruh signifikan terhadap penyerapan tenaga kerja pada sektor perhotelan $(Y)$.

$H_{14}$ Variabel upah minimum karyawan $\left(\mathrm{X}_{4}\right)$ berpengaruh signifikan terhadap penyerapan tenaga kerja pada sektor perhotelan $(Y)$.

Berdasarkan hasil estimasi model fixed effect, diperoleh nilai thitung masing-masing variabel sebagai dijelaskan oleh Tabel 6.

Tabel 6. Uji Parsial (uji $t$ )

\begin{tabular}{ccccc}
\hline Variable & Coefficient & Std. Error & t-Statistic & Prob. \\
\hline C & $-101,3430$ & 88,21184 & $-1,148859$ & 0,2561 \\
$X_{1}$ & 0,872430 & 1,115384 & 0,782178 & 0,0378 \\
$X_{2}$ & 0,190559 & 0,309740 & 0,615224 & 0,0412 \\
$X_{3}$ & 0,125480 & 0,251886 & 0,198164 & 0,6206 \\
$X_{4}$ & 0,000037 & 0,000041 & 0,896238 & 0,0314 \\
\hline
\end{tabular}

Sumber: hasil output Eviews 10

Berdasarkan Tabel 6, diperoleh nilai probabilitas masing-masing variabel dapat dilihat bahwa nilai probabilitas (Sig.) untuk variabel $X_{1}, X_{2}$ dan $X_{4}$ kurang dari 0,05 . Hal ini dapat disimpulkan bahwa variabel jumlah akomodasi $\left(X_{1}\right)$, jumlah kamar hunian $\left(X_{2}\right)$ dan upah minimum karyawan $\left(X_{4}\right)$ mempunyai pengaruh terhadap pernyerapan tenaga kerja pada sektor perhotelan di Provinsi Maluku. Sedangkan variabel banyaknya tempat tidur yang tersedia tidak mempengaruhi penyerapan tenaga kerja pada sektor perhotelan di Provinsi Maluku.

\section{SIMPULAN}

Berdasarkan hasil penelitian yang diperoleh maka penelitian ini dapat disimpulkan bahwa model yang layak digunakan untuk menganalisis pengaruh jumlah akomodasi, jumlah hunian, jumlah tempat tidur yang tersedia dan upah minimum karyawan terhadap terhadap penyerapan tenaga kerja 
pada sektor perhotelan di Provinsi Maluku yaitu Fixed Effect Model. Selain itu, terdapat tiga variabel yang berpengaruh terhadap penyerapan tenaga kerja pada sektor perhotelan di Provinsi Maluku yaitu jumlah akomodasi, jumlah hunian dan upah minimum karyawan sementara jumlah tempat tidur yang tersedia tidak memiliki pengaruh terhadap penyerapan tenaga kerja pada sektor perhotelan di Provinsi Maluku.

\section{REFERENSI}

Alghofari, F., \& Pujiyono, A. (2011). Analisis tingkat pengangguran di Indonesia tahun 1980-2007 (Doctoral dissertation, Universitas Dlponogoro).

Candradewi, M. R. (2016). Pengaruh Kinerja Keuangan Terhadap Return Saham Pada Perusahaan LQ45 di BEl: Analisis Regresi Data Panel. E-Jurnal Ekonomi dan Bisnis Universitas Udayana, 5, 2091-2122.

Gujarati, D. N. (2003). Data disk to accompany Basic Econometrics.

Jaya, I. G. N. M., \& Sunengsih, N. (2009). Kajian Analisis Regresi dengan Data Panel. In Prosiding Seminar Nasional Penelitian. Universitas Negeri Yogyakarta, Yogyakarta.

Kencana, E. N. (2019). Memodelkan Indeks Pembangunan Manusia Provinsi Bali dengan Regresi Data Panel. Jurnal Ekonomi Kuantitatif Terapan, 12(2), 241-247.

Kurniawan, D. (2008). Uji t 2-Sampel Independen. Jurnal Statistik.

Matdoan, M. Y. (2020). Estimasi Parameter Regresi Quantil Dengan Regresi Robust Least Trimmed Square (LTS) (Studi Kasus: Faktor-Faktor yang Mempengaruhi Penyebaran Penyakit Malaria di Indonesia). Jurnal Riset dan Aplikasi Matematika (JRAM), 4(1), 50-62.

Melliana, A., \& Zain, I. (2013). Analisis Statistika Faktor yang Mempengaruhi Indeks Pembangunan Manusia di Kabupaten/Kota Provinsi Jawa Timur dengan Menggunakan Regresi Panel. Jurnal Sains dan Seni ITS, 2(2), D237-D242.

Nachrowi, D. N. \& H. Usman. (2006). Pendekatan Populer dan Praktis Ekonometrika untuk Analisis Ekonomi dan Keuangan. Jakarta: Lembaga Penerbit FE UI.

Ningsih, F. R. (2011). Pengaruh inflasi dan petumbuhan ekonomi terhadap pengangguran di Indonesia.

Pangestika, S. (2015). Analisis Estimasi Model Regresi Data Panel dengan Pendekatan Common Effect Model (CEM), Fixed Effect Model (FEM), dan Random Effect Model (REM). Skripsi. Jurusan Matematika Fakultas Matematika dan Ilmu Pengetahuan Alam Universitas Negeri Semarang.

Setiawan \& Yuliati, L. (2019). Analisis Faktor-Faktor yang Mempengaruhi Tingkat Pengangguran di Provinsi Jawa Timur Tahun 2009-2015. Jurnal Ekuilibrium, 1(1), 31-37.

Simanjuntak, P. J. (2001). Pengantar Ekonomi Sumber Daya Manusia Edisi 2001. Jakarta: FEUI, 62.

Simanjuntak, D. K., \& Rahmadi, S. (2016). Analisis pengaruh belanja modal, PMA dan angkatan kerja terhadap PDRB di Provinsi Jambi. E-Jurnal Ekonomi Sumberdaya dan Lingkungan, $5(3)$.

Sriyana, J. (2015). Metode Regresi Data Panel: Dilengkapi Analisis Kinerja Bank Syariah di Indonesia. Yogyakarta: Ekonisia, FE UII. 
Sukmawati, U. S. (2018). Analisis pengaruh indeks pembangunan manusia (IPM), pertumbuhan ekonomi, dan pengangguran terhadap kemiskinan di Indonesia (2013-2017) (Doctoral dissertation, UIN Walisongo).

Syukriyah, A. (2011). Analisis heteroskedastisitas pada regresi linier berganda (Doctoral dissertation, Universitas Islam Negeri Maulana Malik Ibrahim).

Wijayanti, S. L. (2018). Usaha Mandiri Masyarakat Sebagai Upaya Mengurangi Pengangguran di Kecamatan Kanor Kabupaten Bojonegoro (Doctoral dissertation, Universitas Bojonegoro). 